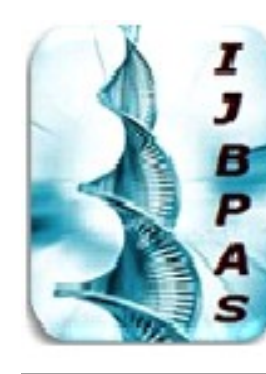

International Journal of Biology, Pharmacy and Allied Sciences (IJBPAS)

'A Bridges Betuen Caboratory and Render'

Www.iibpas.com

\title{
NUTRITIONAL EVALUATION OF VALUE ADDED CHOCOLATE BROWNIE BY
} INCORPORATING AMARANTHUS POWDER

\author{
MISHRA $P^{1^{*}}$, THUKRAL $B^{2}$ AND PRABHLEEN ${ }^{3}$
}

1: Assistant Professor, Department of Nutrition \& Dietetics, FAHS, MRIIRS, Faridabad, Haryana, India

2: Associate Professor, Department of Nutrition \& Dietetics, UIAHS, Chandigarh University, Gharuan Mohali-140413, India

3: M.Sc (N\&D), Department of Nutrition \& Dietetics, FAHS, MRIIRS, Faridabad, Haryana, India

*Corresponding Author: E Mail: priya.fas@mriu.in

Received $15^{\text {th }}$ Dec. 2019; Revised $13^{\text {th }}$ Jan. 2020; Accepted $14^{\text {th }}$ Feb. 2020; Available online $1^{\text {st }}$ Aug. 2020

\section{https://doi.org/10.31032/IJBPAS/2020/9.8.5167}

\begin{abstract}
ABSTACT
In India, the prevalence of anaemia is high in more than half of population i.e. 56\% (64 million) Amaranthus is an ancient grain which is high in iron that has been a dietary staple in certain parts of the world and it can help eradicate the iron deficiency. Amarathus has impressive health benefits (collectively known as amaranth) such as help in lowering cholesterol levels; it is naturally gluten free, rich in fibre and other micronutrients. Amaranth was added to chocolate brownies to enhance the nutritional content of iron in it. The aim is to increase iron content in chocolate brownies. Objectives of this study were to assess the sensory evaluation by 9-point hedonic scale of the brownies. Collection of raw material was done. Further processing of amaranth was continued by roasting the seeds and grinding them into powder form. Later it was divided into two concentrations i.e., T0 CONTROL $=$ BROWNIE (refined flour, gm.), T1 Amaranth $=70 \%$, refined flour $=10 \%$, sugar $=15 \%$, butter $=5 \%$. T2 Amaranth $=60 \%$, refined flour $=15 \%$, sugar $=20 \%$, butter $=5 \%$. Sensory evaluation was done using 9 point Hedonic scale. The proximate analysis of the product was done for nutritional value (energy, protein, fat
\end{abstract}


and $\mathrm{CHO}$ ), ash, moisture, iron. Statistical analysis was done using SPSS version 21. The result showed that the highest acceptance for amaranth chocolate brownie was sample B, consisting of $60 \mathrm{~g}$ of amaranth powder which can be helpful for anaemic patients.

\section{Keywords: amaranth, anaemic, brownie, chocolate, shelf life}

\section{INTRODUCTION}

Iron deficiency is the most common cause of anaemia in the world. It is caused by less number of red blood cells in the blood. Blood basically consists of smaller size of red blood cells than normal (microcytic) and carries reduced amount of haemoglobin [1]. Due to heavy blood loss anemia can easily shoot up and reason could be heavy periods, stomach ulcers, urinary tract bleeding, and colon cancer and child birth [2]. Diseases like HIV/AIDS can also be increased risk of iron deficiency anemia [3]. Iron deficiency can be treated by food which contains high amount of iron to it or iron supplementation. Foods which are rich in iron content are green leafy vegetables, lentil and beans nuts and seeds [4] In case of serious patients, blood transfusion can be opted and iron injections can be given too [5]. The common symptoms any individual shows initially are fatigue, skin pallor, and shortness of breath, dizziness or a fast heartbeat. Deficiency of iron affected more than 54000 people in 2015 eventually they died too [6]. Women and young children become the prior target. It is not always necessary for a patient to experience symptoms for anemia, sometimes patients may experience sign of pallor (reduced oxy hemoglobin in skin or mucous membranes) none of them are any specific or sensitive symptoms. In children there is pallor of mucous membrane (primarily the conjunctiva), various studies showed that pallor of the mucous membranes is only "28\% sensitive" and "87\% specific" (with high predictive value) in anemic children(defined as hemoglobin $<11.0 \mathrm{~g} / \mathrm{dl}$ ) and " $49 \%$ sensitive" and " $79 \%$ specific" in distinguishing severe anemic patients (hemoglobin $<7.0 \mathrm{~g} / \mathrm{dl}$ ) [7].

Another risk factor includes children who have more of lead in their environment, therefore it, interrupts the absorption of iron. Secondly, family history and genetic can also contribute in iron absorption in case of trauma, surgery or heavy menstrual periods can increase the of iron deficiency, lifestyles habits and consumption of the food plays an vital role for instance if the person is having a vegetarian or vegan pattern then the requirement won't be fulfilled also frequent blood donation. In case of marathon runners haemolysis occurs because of the muscle contraction and the pressure of feet 
repeatedly striking on the ground, especially in young females.

During pregnancy, after delivery or breast feeding one may not meet the requirement of iron because the body is already demanding more of it. During the period of growth and development food alone cannot complete it. Haemoglobin level should always remain between, "in male is 14 to $18 \mathrm{~g} / \mathrm{dl}$; that for females is 12 to 16 $\mathrm{g} / \mathrm{dl}$. When it falls below this level the individual has anemia" [8].

The prior sources of iron are meat, fish and poultry, fruits and vegetables, cereals and grain, dairy products, soy products, nuts and seeds [9]. Amaranth is one of the high sources of iron. "Raw amaranth grain has $12 \%$ water, $65 \%$ carbohydrates, $7 \%$ of dietary fiber, $14 \%$ of protein, and $7 \%$ of fat. In 100 gram of amaranth there are 371 calories and has other vital micronutrients also". Focusing on iron, iron content in amaranth is $59 \%$ which exactly gives us more than $9 \mathrm{mg}$ of iron of the daily value [10].

Baking is one of the most popular methods of cooking. Baked goods are revolving around for thousands of years. This art initially stared in Rome; earlier baking was happily done at all the important occasion and was done by specific individuals. This trend spread like around the world and became highly common. The demand significantly increased and became a common place to buy delicious goods [11, 12]. Cakes and brownies were the most common method of consuming food in a way that they are more delicious act as a desert and are absolutely fulfilling.

\section{Inclusion of amaranth in chocolate brownies}

Inclusion of amaranth with brownies can easily increase the iron content of the brownie and can be consumed by all the iron deficit individuals. Amaranth can be used as a primary ingredient while making chocolate brownies. Anemia can be triggered by the combination of these. All these above mentioned causes can be treated by consuming amaranth chocolate brownies.

\section{MATERIALS \& METHODS}

The study is conducted in Manav Rachna International Institute of Research \& Studies (MRIIRS), Faridabad. Amaranthus seeds are procured from Delhi by the student and chemical evaluation is done in the Department of Nutrition \& Dietetics, LAB.

The seeds are cleaned, roasted, processed and then converted in to powder. The fine powder is added in to the brownie batter in two different compositions with control.

Composition of Amaranth Chocolate Brownies: (Table 1) 
- T0 CONTROL = BROWNIE(refined flour, gm)

- T1 Amaranth $=70 \%$, refined flour $=10 \%$

- T2 Amaranth $=60 \%$, refined flour $15 \%$

Nutritional \& Sensory evaluation was done for all three compositions. It is basically a simple way that applies the human senses (sight, smell, touch, taste and hearing for the purpose of evaluating consume products. This requires two panels, one is the trained panel and the other is untrained panel. Later the product is tested by them and data is recorded accordingly. In this research study amaranth chocolate brownies were analysed Under proximate analysis, Energy, Protein, Fat, Carbohydrate, Iron, Ash Content, Moisture Content, Dietary Fibre.. It also depicts the nutritional and biochemical content of the product through which it can be easily estimate that how beneficial the product is for consumption. The Table 2 depicts the nutritional value of the product that is value added brownie.

Table 1: Recipe for Chocolate Brownie

\begin{tabular}{|c|c|c|c|}
\hline Ingredients & Standard & Sample 1 & Sample 2 \\
\hline Refined flour & $1^{1 / 3}$ cups & 10 gram & 15 gram \\
\hline Butter & 40 grams & 5 gram & 5ram \\
\hline Castor sugar & 40 grams & 20 gram & 20 gram \\
\hline Cocoa & 60 gram & 10gram & 10 gram \\
\hline Amaranth & --- & 60 grams & 50 grams \\
\hline Water( Luke warm) & 1 cup & 1 cup & 1 cup \\
\hline Baking soda & Pinch & Pinch & Pinch \\
\hline Baking powder & Pinch & Pinch & Pinch \\
\hline Vanilla essence & 1 teaspoon & 1 teaspoon & 1 teaspoon \\
\hline
\end{tabular}

Table 2: Nutritional Facts of Amaranth Chocolate Brownie Through Proximate Analysis (per 100 gram)

\begin{tabular}{|c|c|}
\hline Parameters & Results \\
\hline Energy & $489.5 \mathrm{Kcal}$ \\
\hline Protein & $3.87 \mathrm{~g}$ \\
\hline Total fat & $\mathbf{2 8 . 7 \mathrm { g }}$ \\
\hline Total carbohydrate & $\mathbf{5 4 . 6 \mathrm { g }}$ \\
\hline Iron & $\mathbf{7 . 8 5} \mathrm{mg}$ \\
\hline Ash content & $\mathbf{4 . 2 1 \%}$ \\
\hline Moisture content & $\mathbf{3 1 . 5 \%}$ \\
\hline Dietary fibre & $\mathbf{6 . 4 g}$ \\
\hline
\end{tabular}

\section{RESULTS AND DISCUSSION}

This study was conducted to increase the iron content of chocolate brownies by adding amaranth into it. Amaranth is a pseudo cereal grain which can be grown on unused land. It is cheap, easily available and full of nutrition, therefore, can be consumed by all the socio-economic groups. In this study it was concluded that amaranth can be used to fulfil the requirement of iron. Since, 
the prevalence of iron deficiency anaemia is increasing rapidly, value added amaranth.

\section{CONCLUSION}

Chocolate brownies can help to cure iron deficiency in all the age groups. Further the result also depicted that according to the percentage acceptability of the colour, $42 \%$ of individuals extremely liked the sample B, in percentage acceptability of the taste, $40 \%$ of individuals liked the sample $B$, in percentage acceptability of texture, $32 \%$ of individuals liked the sample $\mathrm{A}$, in percentage acceptability of aroma, $34 \%$ of individual liked sample, and percentage acceptability of appearance, $38 \%$ of individuals liked sample B. This further stated that sample B is most accepted by subjects. The product developed provides sufficient amounts of iron to meet the daily recommended amount of the individual.

\section{REFERENCES}

[1] https://doi.org/10.1136/bmj.314.7077. 360 (Published 01 February 1997)

Cite this as: BMJ 1997; 314:360 (published 01 february 1997).

[2] Kadian S., Kaur A., Singh J, (2017), Understanding the Burden of Anaemia among Children in Northeastern States, India: Evidence From National Family Health Survey,
Demography India, Special Issue, ISSN: 0970-454X, pp: 138-142.

[3] Kassebaum NJ; GBD 2013 Anaemia Collaborators. The global burden of anemia. Hematol Oncol Clin North Am. 2016; 30(2): 247-308.

[4] Gamel T.H., Linssen J.P., Mesallam A.S., Damir A.A., Shekib L.A. (2005): Effect of seed treatments on the chemical composition of two amaranth species: starch and protein. Journal of the Science of Food and Agriculture, 85: 319-327

[5] Hauptli H (1977) In: Proceedings of the first amaranthus seminar, agronomic potential and breeding strategy for grain amaranthus. Rodale Press, Emmaus, PA, pp 71-83 14.

[6] Sindhuja A., Sudha M.L., Rahim A. (2005): Effect of incorporation of amaranth flour on the quality of cookies. European Food Research and Technology, 221: 597-601.

[7] Saunders, R.M. and Becker, R. (1984). Amaranthus: a potential food and feed resource. In: Pomeranz Y (ed) Advances in cereal science and technology. CRC Press, USA. 4: 357-396. J.Cereal Sci. 30: 169-202

[8] Hoseney RC, Rogers DE (1994) Mechanism of sugar functionality in cookies: the science of cookie and 
cracker production, Ist edn. In: Faridi

$\mathrm{H}$ (ed) American Association of

Cereal Chemists, St. Paul, MN, pp

203-225 24.

[9] Bodroza, Solarov, M., Matilovic, J.,

Keveresan, Z. and Filipev, B. (2003).

Snack products of Amaranthus

cruentus. In "Proceedings of

International Congress, $4^{\text {th }}$ Crotian

Congress of Cereal Technologist".

250-255.

[10] Steel RGD, TorrieJH (1980)

Principles and procedures of

statistics, $2^{\text {nd }}$ edn. McGraw-Hill,

New York 22.

[11] Jauregui, R. N., Silva, M.E.P. and

Areas, J.A.G. (2000). Extrusion

cooking process for amaranth

(Amaranthus caudatus L.). J. Food

Sci. 65 (6): 1009-1015

[12] Ilo, S., Liu, Y. and Berghofer, E. (1999). Extrusion cooking of rice flour and amaranth blends. Lebensm

Wiss.u.Technol. 322: 79-88. 